\title{
İklim Değişikliği Konusunda Orman Fakültesi Öğrencilerinin Bilgi Düzeylerinin Belirlenmesi (Kastamonu Üniversitesi Orman Fakültesi Örneği)
}

\author{
Yavuz GÜLOĞLU ${ }^{1}$, *Alper BULUT ${ }^{2}$ \\ ${ }^{1}$ Kastamonu Üniversitesi, İktisadi İdari Bilimler Fakültesi, KASTAMONU \\ ${ }^{2}$ Kastamonu Üniversitesi, Orman Fakültesi, Orman Mühendisliği Bölümü, KASTAMONU \\ *Sorumlu yazar: abulut@kastamonu.edu.tr
}

Geliş Tarihi:28.10.2016

\begin{abstract}
Özet
İklim değiş̧ikliği günümüz dünyasını ilgilendiren önemli sorunlardan birisidir. Dünyadaki iklim olaylarında yaşanan birçok dengesizlik bu olguya olan ilgiyi gittikçe arttırmış ve alınması gereken tedbirlere ilişkin birçok öneri ortaya konulmuştur. İklim değişikliğinin önlenmesinde sera gazlarının salınımının etkisi azımsanmayacak derecede önemlidir. Sera gazlarının salınımının azaltılması ile birlikte karasal ekosistemler içeresinde en büyük depolama kaynağı olan orman alanlarının arttırılması iklim değişikliğinin önlenmesinde büyük katkı sağlayacaktır. Gelecekte orman ekosistemlerinin ve orman ürünleri sektörünün yöneticileri olacak orman mühendislerinin ve orman endüstri mühendislerinin konuya ilişkin bilgi düzeyleri oldukça önemlidir. Bu çalışmada Kastamonu Üniversitesi Orman Fakültesi Orman Mühendisliği ve Orman Endüstri Mühendisliği Bölümü öğrencilerine iklim değișikliği konusu ile ilgili anket yapılmış ve bu anketlere göre öğrencilerin konuya ilişkin bilgi düzeyleri belirlenmeye çalışılmıştır. Anket çalışması 216 orman mühendisliği, 92 orman endüstri mühendisliği bölümü öğrencisi olmak üzere toplam 308 öğrenci üzerinde gerçekleştirilmiştir. Anketlerin analizinde, yüzde yöntemi, frekans tabloları ve Ki-kare testi kullanılmıştır. Çalışmanın sonucunda, Orman Mühendisliği Bölümü öğrencileri \%94, Orman Endüstri Mühendisliği Bölümü öğrencileri ise \%91 oranında "İklim Değişikliği" kavramına inanmakta oldukları belirlenmiştir. Ayrıca birçok soruya verilen cevaplara öğrencilerin bölümlerinin ya da cinsiyetlerinin istatistiki olarak etki etmediği tespit edilmiştir.
\end{abstract}

Anahtar Kelimeler: İklim değişikliği, Ormancılık Eğitimi, Kastamonu

Determining the Knowledge Level of the Forestry Faculty Students about Climate Change (a Case Study of Kastamonu University Forestry Faculty)

Abstract

Climate change is a very important trouble for the todays world. Many uncertainties we are having today about climatic events gradually increase the attention given to do subject and presented many crucial precautions we are currently trying to draft about it. The effect of greenhouse gas emissions is critical in climate change. Besides, along with a decrease in the emission of greenhouse gases, the acreage wise increase in the forest areas all over the World will immensely contribute to slowing down of the climate change phenomenon.The approach and viewpoint of forest and forest products engineering students who will govern the forest ecosystems and forest products sector in the near future will extremely be significant.Thus, in this particular study, a survey was carried out with the students of Kastamonu University, Faculty of Forestry and the understanding of the subject was questioned 216 forest engineering and 92 forest products engineering students took part in the survey. Percentage analysis, frequency tables and chi square test were used the analysis of surveys. As the result of the study, it was validated that $94 \%$ of the forest engineering students and $91 \%$ of the forest products students are firmly believing the concept of "Climate Change". Besides, it was also determined that professional or gender differences among the students did not make any statistically significant effect on their responses.

Keywords: Climate change, Foresty education, Kastamonu

\section{Giriş}

Çevresel sorunlar teknolojinin gelişimi, hızlı nüfus artışı ve kıt olan kaynakların hoyratça kullanılması ve benzeri sebeplerle artmış ve bazen felaketlere sebep olacak sonuçlar doğurmuştur. Bugün hemen hemen bütün iklimbilimciler tarafindan, dünya iklimi sisteminde bir bozulmanın olduğu kabul edilmektedir. Doğal dengenin bozulmasına neden olan insanların, gerekli önlemler alınmadan çeşitli etkinliklerinin devam etmesi hâlinde, iklimdeki bu bozulmaların daha da artacağı, sonucu çok olumsuz olabilecek küresel 1sınmaya bağlı iklim değişikliklerinin yaşanacağ 1 , kesin bir dille ifade edilmektedir. Çünkü beşerî nedenlerle, atmosferdeki sera gazı birikimlerinde ve partiküllerde meydana gelecek artış, doğal çevrenin tahribi, ozon 
tabakasındaki incelme, küresel boyutta sıcaklık artışına neden olacaktır (Öztürk, 2002).

Dünyanın, özellikle sanayi devriminden sonraki iki yüz elli yıllık süreçte ekonomik anlamdaki kalkınması ve büyümesi gerçekleşmiştir. İnsanların bu iki yüz elli y1llık dönemde gerçekleștirdiği ekonomik faaliyetler için ihtiyaç duyduğu tüm enerji fosil kaynaklı ve yoğun karbondioksit $\left(\mathrm{CO}_{2}\right)$ salan kaynaklardan elde edilmiștir (Yalçın, 2010; Bayrak, 2012). Fosil yakıtların kullanımı ve dünya üzerinde yaygın olarak görülen ormansızlaşma, atmosferdeki $\mathrm{CO}_{2}$ konsantrasyonu sanayi devriminden bugüne 2000'li yılların başına kadar \%25 artmıştır (Houghton ve Woodwell, 1989, Mitchell, 1989; Short ve Neckles, 1999). 2000 yılından atmosferdeki $\mathrm{CO}_{2}$ miktarı yaklaşı $365 \mathrm{ppm}$. Olarak ölçülmüşken, 2016 yılının Ekim ayında yaklaşık 401 ppm. olarak ölçülmüştür. (URL-1). Metan, azot oksit, gibi diğer gazların konsantrasyonu da insan aktiviteleri ile birlikte artmaktadır (Short ve Neckles, 1999). Ayrıca, kloroflorokarbonların ve diğer klorlu ve bromlu bileşiklerinin birikmesi ile Dünya yüzeyinde ultraviyole (UV) radyasyon oluşmakta ve bu radyasyonun artışı sonucu stratosferik ozon tabakasına zarar vermektedir (Worrest, 1989; Smith ve ark, 1992; Short ve Neckles, 1999). Dünyanın ortalama yüzey sıcaklığı, artan karbon dioksit ve diğer insan kaynaklı emisyonların atmosfere salınımı sonucu 19. yüzyılın sonlarından bu yana yaklaşık $1{ }^{\circ} \mathrm{C}$ yükselmiştir (URL-2). Ne yazık ki bu büyük kalkınmanın ve ekonomik değişimin sonucu bugün, iklim değișimi ve küresel 1sınma olarak insanlara yüklenmiştir (Yalçın, 2010; Bayrak, 2012).

İklim değișikliği konusunda uluslararası birçok anlaşma veya sözleşmeler imzalanmıştır. Yaklaşık son yirmi yıllık bir süreçte, iklim değişikliğinin önlenmesi ve iklim değişikliği ile alakalı hükümetler arasında görüşmeler, uluslararası bilimsel ve teknik bilgi edinme, yapılanma ve hukuki çerçeve hazırlıkları gerçekleşmiştir (Türkeş, 2000 Türkeş, 2001). 1997'de imzalanan Kyoto Protokolü iklim değișikliği ve ormancılık açısından çok önemli bir yere sahip olan bir anlaşmadır. Birleşmiş Milletler İklim Değişikliği Çerçeve Sözleşmesi içinde bulunan Kyoto Protokolü, küresel isınma ve iklim değişikliği konusunda mücadeleyi sağlamaya yönelik uluslararası tek çerçevedir (Bulut, 2012). Şimşek'e (2016) atfen "Kyoto protokolü ile sera etkisine yol açan karbondioksit ve diğer beş gazın salınınım azalt1lmas1 konusunda yeni bir rejim oluşturmuştur". Bununla birlikte halen yeni çalışmalar küresel ölçekte devam etmekle birlikte bireysel olarak insanların iklim değişikliğine olan etkileri de oldukça önemlidir. Birey olarak karbon ayak izini en yüksek oranda etkileyen faktörler arasında $\% 15$ ile fosil kaynakların kullanımıdır. Aynı zamanda \%14 eğlence, gezme ve tatil aktivitelerinden oluşmaktadır (URL-3).

Devam eden bu çalışmalar 1şı̆̆ında, çevresel sorunların en önemli çözüm noktası olan kamuoyunun bilinçlendirilmesi kısmında bazı sıkıntılar çekilmektedir. Bu noktada, iklim değişikliğinin önlenmesinde önemli bir paya sahip olan orman ekosistemlerinin yönetilmesinde uygulanacak olan esaslar ve bireylerin bu bakış açsıyla doğaya ve onun önemli bir parçası olan ormanlara karşı tutum ve davranışları oldukça önem taşımaktadır. Ayrıca birey olarak iklim değişikliği konusundaki bilgi düzeyinin ölçülmesi yeni çalışmalara 1şık tutacaktır.

Türkiye'de çevresel sorunlar ve iklim değişikliği konusuna yönelik bilinç düzeyinin ölçülmesine yönelik çalışmalar incelendiğinde; Y1lmaz ve ark. (2002) yılında 1998-1999 öğretim yılında Hacettepe Üniversitesi Eğitim Fakültesi Kimya Eğitimi Anabilim Dalında okuyan 240 öğrenciye, Ankara ve Beypazarın'da altı ortaöğretim okulunda eğitim gören 228 öğrenciye ve 2001-2002 öğretim y1lında yine Hacettepe Üniversitesi Eğitim Fakültesi Kimya Eğitimi Anabilim Dalında okuyan 153 öğrenciye üç farklı anket uygulanmıştır. Çalıșma sonucunda çevre konusunda verilen eğitimin yetersiz olduğu, özellikle ortaöğretimde kimya dersi alan öğrencilerin konu hakkında daha bilgili oldukları ve öğrencilerin çevre ile ilgili bilgilerinin daha fazla yazılı ve görsel medyadan edindikleri ortaya konmuştur. Şama (2003), Gazi Üniversitesi Eğitim Fakültesi öğrencilerinin çevre sorunlarına yönelik tutumlarının belirlenmesini amaçlamıştır. Erol ve Gezer (2006)'nın çalışmasında üniversite öğrencilerinin çevre ve çevre sorunlarına tutumlarının anlaşılması 
için 2003-2004 yılında Pamukkale Üniversitesi Eğitim Fakültesi İlköğretim Bölümü Sınıf Öğretmenliği Anabilim Dalı 2. Sınıf öğrencilerine yaptığı anketler sonucu kız öğrencilerin tutumlarını olduğu istatistiksel olarak ortaya konulmuştur. İncekara ve Tuna, (2010) tarafindan Çankırı ili örneğinde ortaöğretim seviyesinde farklı okul türlerinde öğrenim gören öğrencilerin çevre ile ilgili çeşitli olgular hakkındaki bilgi seviyelerinin ortaya çıkarılmasını hedeflemekle birlikte, öğrencilerin ilgili konulardaki altyapılarının cinsiyet ve alan gibi demografik özelliklere göre farklılașıp farklılașmadığını incelemiștir. Ankara'da, Oğuz, Çakcı ve Kavasa (2011) tarafindan yapılan çalışmada Peyzaj Mimarlı̆̆ı, Çevre Mühendisliği ve Şehir ve Bölge Planlama programlarında öğrenim gören öğrencilerin çevre konularında farkındalık, bilinç ve duyarlılık düzeylerinin belirlenmesini amaçlanmıştır. Çalışma kapsamında ilgili bölümlerin birinci ve dördüncü sınıflarında okuyan 213 öğrenciye anket çalışması uygulanmıştır. Öğrencilerin çevre ile ilgili konularda farkındalık ve duyarlılık seviyesinin okudukları sinıflardan bağımsız olduğu, çevresel sorunlar ve kaynakların korunması konusunda her ne kadar kavramsal bilgiye sahibi olsalar da normal yaşamlarında davranışlarının ve tutumlarının aynı düzeyde olmadığı belirlenmiştir. Bozdoğan ve Yanar (2009) tarafindan yapılan çalışmada, "Sınıf Öğretmeni Adaylarının Küresel Isınmanın Gelecek Yüzyıldaki Etkilerine İlişkin Görüşleri” başlıklı çalıșmasında 68 sınıf öğretmeni adayı üzerinde küresel 1sınmanın gelecekteki etkileri konusundaki düşüncelerini ortaya konulmuştur. Çalışma sonucunda öğretmen adaylarının ilgili konuda yeterli düzeyde bilgiye sahip oldukları tespit edilmiştir.

$\mathrm{Bu}$ çalışmada Kastamonu Üniversitesi Orman Fakültesi Orman Mühendisliği Bölümü $(\mathrm{OM})$ ve Orman Endüstri Mühendisliği Bölümü (OEM) öğrencilerinin iklim değişikliği konusuna ilişkin bilgi düzeylerinin belirlenmesi amaçlanmıştır. İklim değișikliği konusunda orman fakültesi öğrencileri için buna benzer bir çalıșmanın Türkiye'de daha önce yapılmamış olması bu çalışmanın önemini ortaya koymaktadır.

\section{Materyal-Yöntem}

Bu çalışmada, materyal olarak Kastamonu Üniversitesi Orman Fakültesi öğrencileri seçilmiştir. 2006 y1lında kurulan Kastamonu Üniversitesi Orman Fakültesi, bünyesinde Orman Mühendisliği Bölümü, Orman Endüstri Mühendisliği Bölümü, Yaban Hayatı Ekolojisi ve Yönetimi Bölümü olmak üzere üç bölüm barındırmaktadır. Fakat aktif olarak Orman Mühendisliği ve Orman Endüstri Mühendisliği bölümleri eğitim ve öğretime devam etmektedir. Çalışmanın yapıldığı 2013-2014 eğitim-öğretim döneminde Orman Mühendisliği Bölümünde 269, Orman Endüstri Mühendisliği Bölümünde 118 olmak üzere kayıtlı toplam 387 öğrenci bulunmaktadir.

Kastamonu Üniversitesi Orman Fakültesi Orman Mühendisliği Bölümünden 216 öğrenciye, Orman Endüstri Mühendisliği Bölümünden ise 92 öğrenciye olmak üzere toplam 308 anket uygulamas gerçekleştirilmiştir. Anket yapılan ögrencilerin 92'si kadın, 216'si ise erkektir. Anket çalışması ile öğrencilerin iklim değişikliği konusundaki bilgi düzeylerinin ölçülmesi amaçlanmıştır. Bu aşamada anket sorularının değerlendirilmesinde frekans tabloları, yüzde yöntemi ve Ki-kare testi kullanılmıştır. Ho hipotezi "Verilen cevaplara bölümlerin ya da cinsiyetlerin etkisi vardır" şeklinde kurulmuş ve her soru $\% 95$ güven ile test edilmiştir. Anketlerin bir kısmında bazı sorular cevaplanmamış veya öğrenciler tarafindan anketlerin doldurulması esnasinda bazı yanlışlıklar yapılmıştır. Bu durumdaki sorularda meydana gelen hatalar tek tek tespit edilerek, bu anketler (5 adet) çalışma dışında tutulmuştur.

Çalışmada, anket yapılan grup üniversite öğrencilerini kapsadığından ve bu grup için yaş gruplarının en düşük ve en yüksek olduğu aralık çok geniş olmadığından yaş ile ilgili herhangi bir analiz yapılmamıştır.

Yapılan anket çalışmasında öğrencilerin, iklim değişikliğinin ne anlama geldiği, bu konu ile ilgili herhangi bir organizasyon veya topluluk içerisinde bulunup bulunmadıkları, iklim değişikliği ile ilgili bilgileri nerelerden elde ettikleri, iklim değişikliğinin ne anlama geldiği gibi sorular ile birlikte, öğrencilerin yaş, sınıf ve bölümlerini belirleyici sorular sorulmuştur. 


\section{Bulgular}

"Sizce İklim Değişikliği ne anlama gelmektedir" sorusuna verilen cevaplar incelendiğinde;

Bu soruya verilen cevaplar yüzde yöntemi ile analiz edilerek Şekil 1'deki gibi özetlenmiştir. Özet sonucunda, verilen cevaplarda "Mevsimsel düzensizlikler" cevabının oranı her iki bölüm öğrencileri için de en yüksek $(\% 28,0-\% 26,6)$ bulunmuştur.
Ayrıca her iki bölüm öğrencileri için de ikinci en çok tercih edilen cevap $(\% 18,5-\% 18,2)$ "Doğanın dengesinin bozulması" seçeneği olmuştur. Yapılan ki kare testi sonucunda öğrencilerin okudukları bölümün ve cinsiyetlerinin soruya verdikleri cevaba $\% 95$ güven ile etkisinin olmadığı belirlenmiştir. Ki-kare testine ilişkin bulgular Tablo 1'de verilmiştir.

\section{Sizce İklim Değişikliği ne anlama gelmektedir? (\%)}

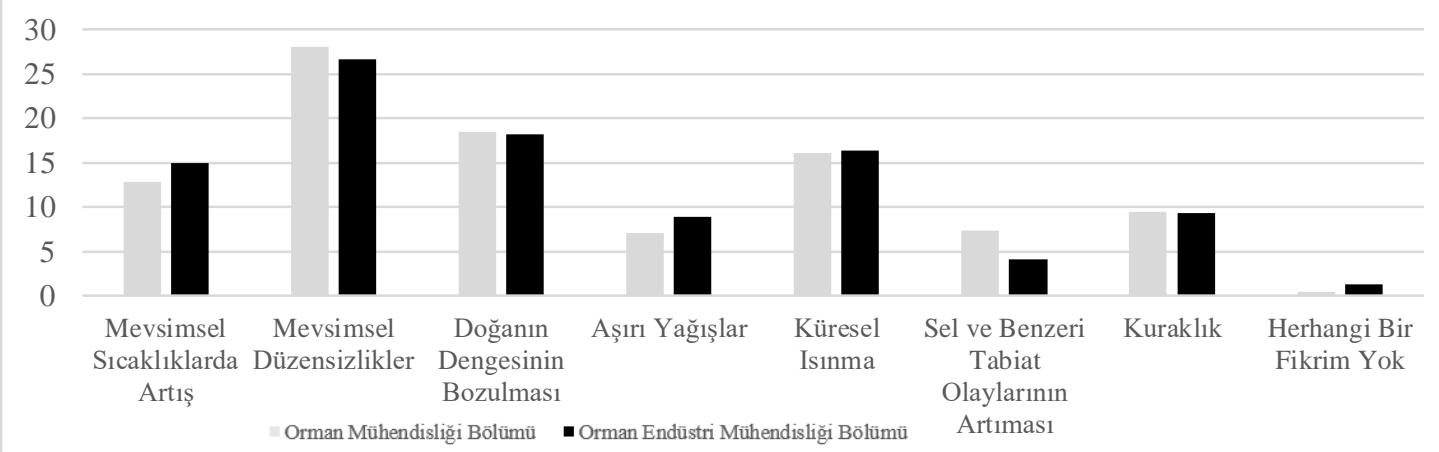

Şekil 1. “Sizce İklim Değişikliği ne anlama gelmektedir?” sorusuna verilen yanıtları yüzdelik olarak gösterir grafik

Tablo1. “Sizce İklim Değişikliği ne anlama gelmektedir?” Sorusuna ilişkin Ki-kare testi sonuçları

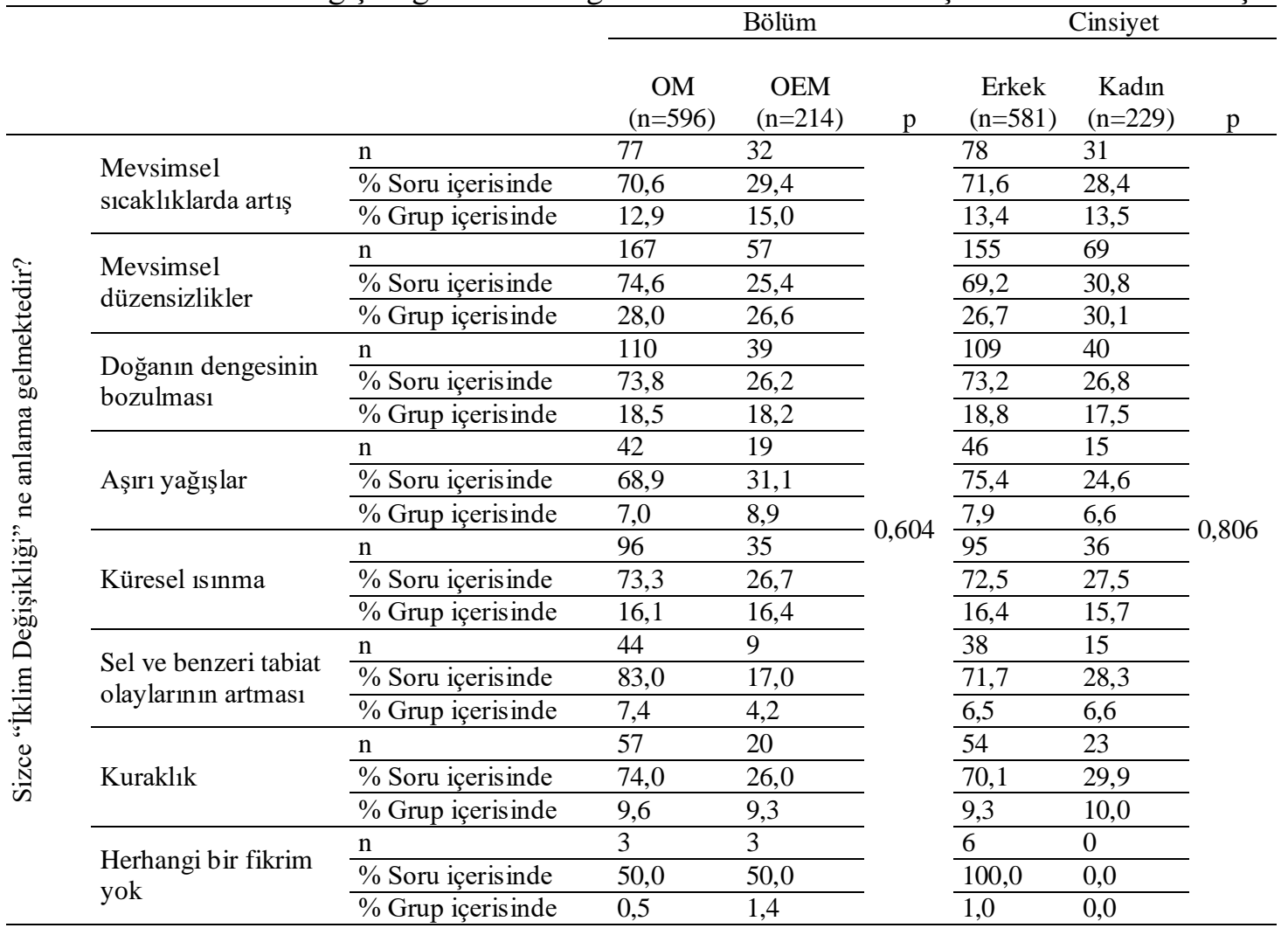


"İklim Değişikliği kavramına inanıyor musunuz?" sorusuna verilen cevaplar incelendiğinde;

OM öğrencilerinin \%94'ünün ve OEM öğrencilerinin \%91'inin "Evet inanıyorum" cevabı verdiği tespit edilmiştir. Bu iki bölüm öğrencilerinin soruya verdikleri cevaplarda bölümlerinin etkisi olup olmadığ test edilmiş ve yapılan Ki-kare testi sonucunda $(\mathrm{p}=0,394)$ öğrencilerin okudukları bölümün ilgili soruya verdikleri cevaba \%95 güven ile etkisinin olmadığı belirlenmiştir. Aynı soruyu cinsiyet ile ilişkilendirdiğimizde cinsiyetin etkisinin olduğu $(\mathrm{p}=0,001)$ tespit edilmiștir. Erkeklerin $\% 17,3$ '̈̈ iklim değişikliği kavramına inanmiyorken, kadınların sadece \%1,1'i inanmamaktadır. Şekil 2'de soruya verilen cevaplar grafik olarak gösterilirken Tablo 2'de Ki-kare testi sonuçları verilmiştir.

\author{
"İklim değişikliğinin sebebi size göre \\ nedir?" sorusuna verilen cevaplar \\ incelendiğinde;
}

$\mathrm{Bu}$ soruya verilen cevaplar yüzde analizi yöntemi kullanılarak Şekil 3'deki gibi özetlenmiştir. Özet sonucunda, verilen cevaplarda OM öğrencileri için "Hızlı Sanayileşme" cevabı en yüksek yüzde ile $(\% 21,4)$ bulunurken, OEM öğrencileri için "Ormanların Yok edilmesi” cevabı en yüksek yüzde olarak $(\% 21,4)$ bulunmuştur. Öğrencilerinin bölümlerinin ve cinsiyetlerinin ilgili soruya verdikleri cevaba etkisinin olmadığı istatistiksel olarak belirlenmiștir. Soruya verilen cevaplara ilişkin Ki-kare testi sonuçları Tablo 3'de verilmiştir.

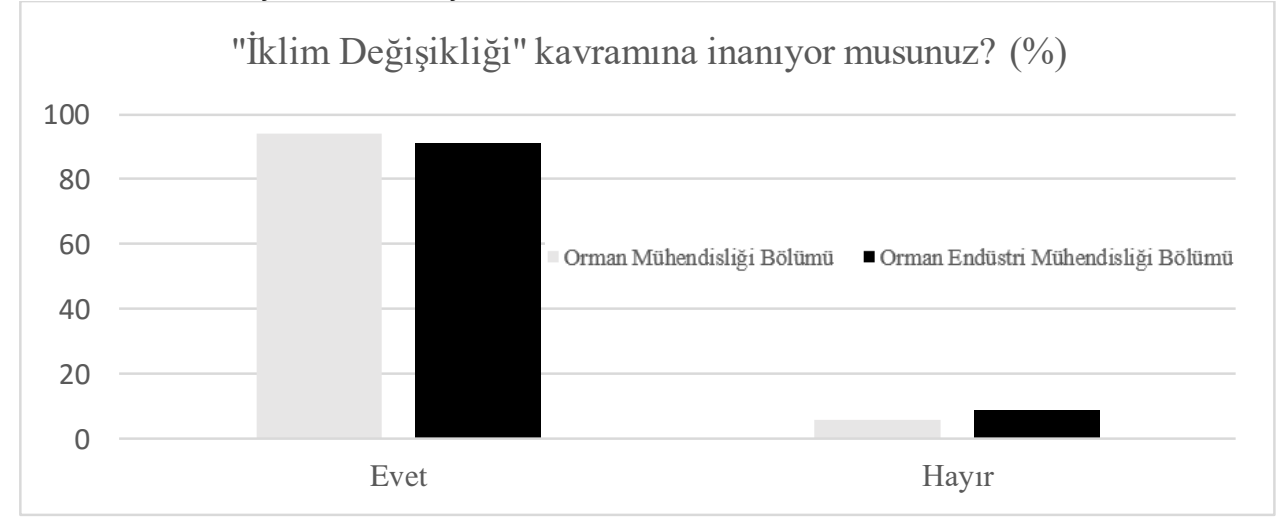

Şekil 2. “iklim Değişikliği kavramına inanıyor musunuz?” Sorusuna verilen cevapları gösterir grafik

Tablo 2. "İklim Değişikliği kavramına inanıyor musunuz?" sorusuna ilişkin Ki-kare testi sonuçları

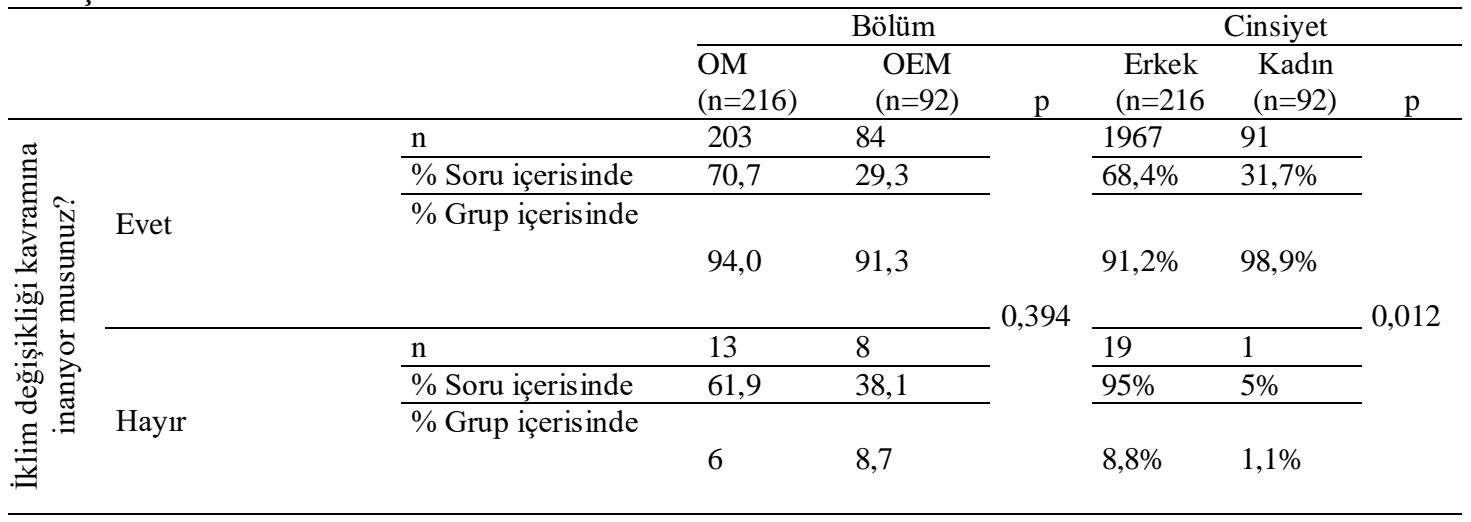




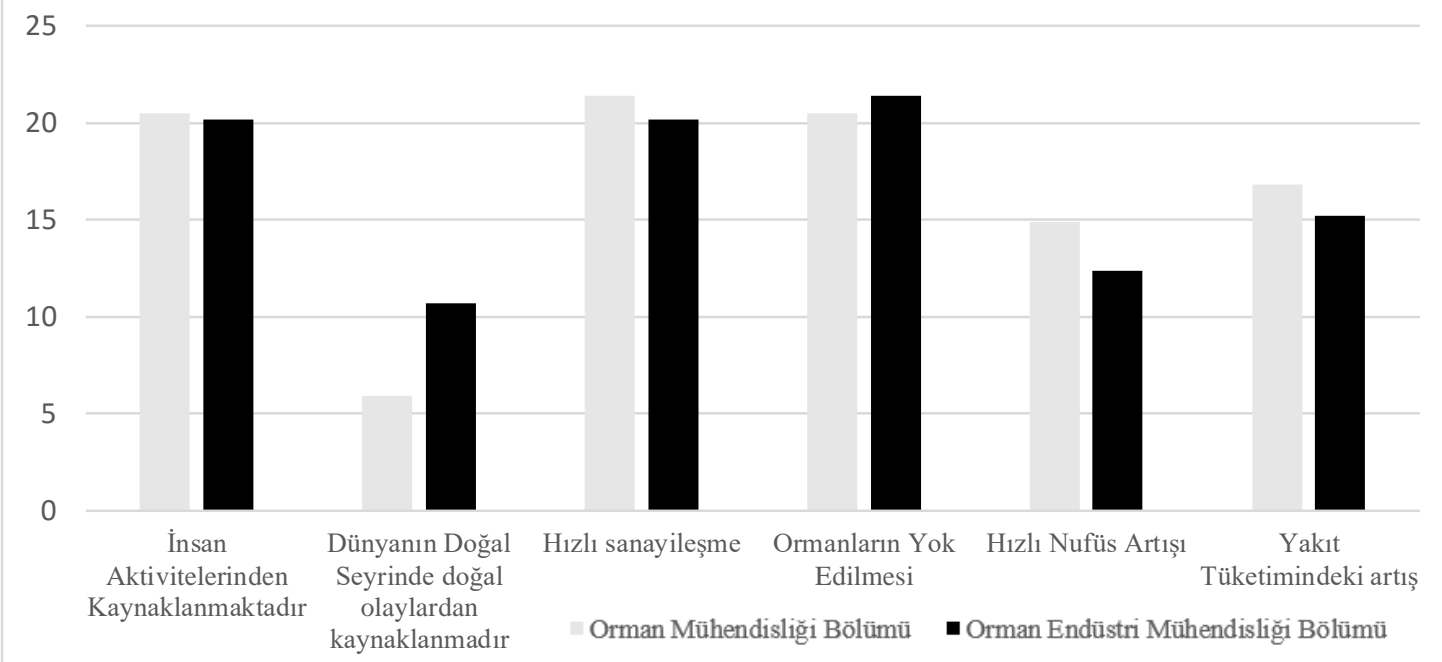

Şekil 3. “İklim Değişikliğinin sebebi size göre nedir?” sorusuna verilen yanıtları yüzdelik olarak gösterir grafik

Tablo 3.“iklim Değişikliğinin sebebi size göre nedir?” sorusuna ilişkin Ki-kare testi sonuçları

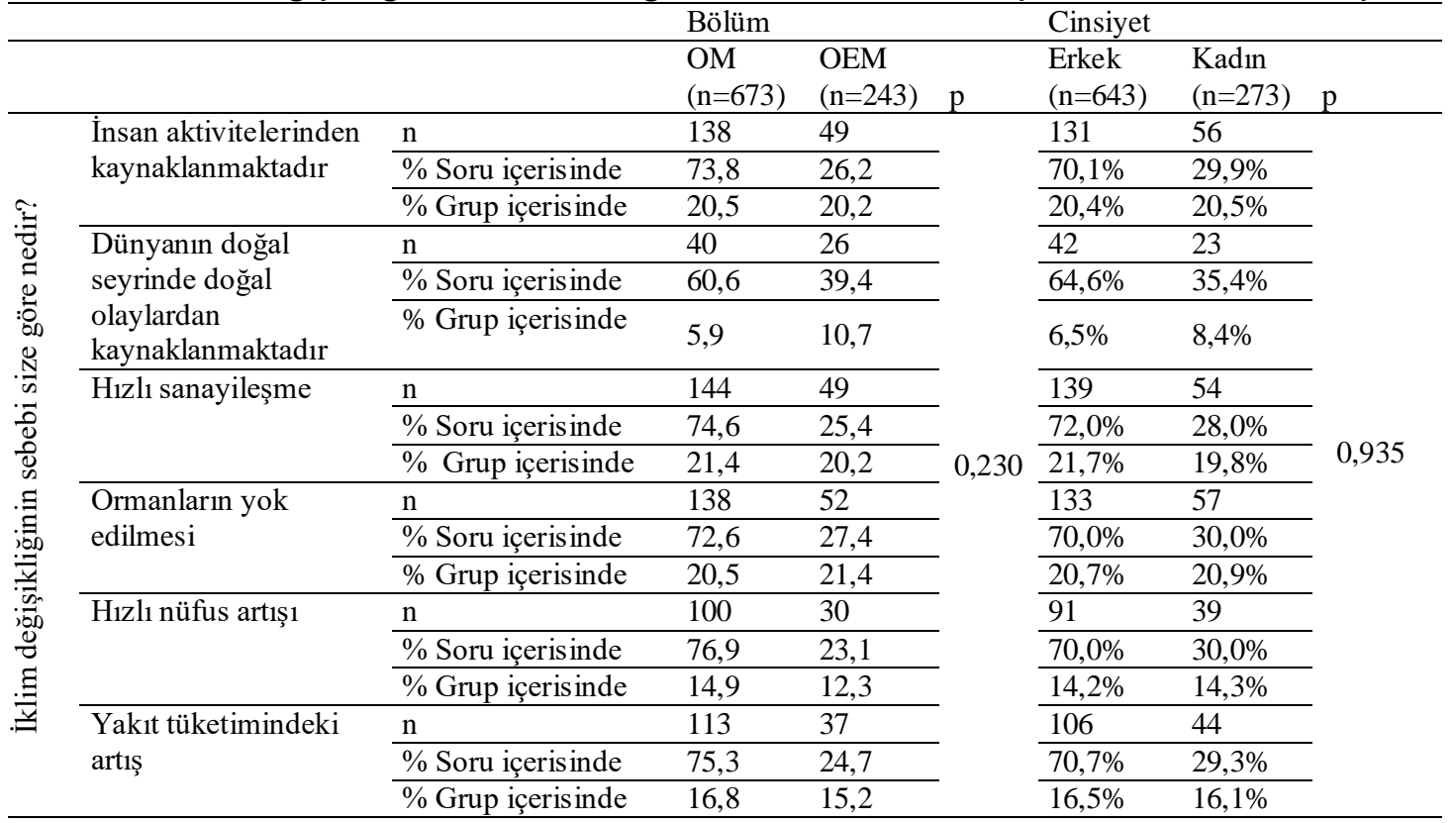

“İklim değișikliğinin sizi ne kadar endişelendirmekte?" sorusuna verilen cevaplar incelendiğinde;

$\mathrm{Bu}$ soruya verilen cevaplarda $\mathrm{OM}$ öğrencileri için \%31,94'lük oranla "Fazla" cevabı en yüksek bulunurken, OEM öğrencileri için \%31,11'lik oranla 'Çok Fazla" cevabı en yüksek bulunmuştur. Verilen cevaplar Şekil 4'deki gibi özetlenmiștir. Ayrıca öğrencilerin ilgili soruya verdikleri cevaplara, okudukları bölümün ve cinsiyetlerinin $\% 95$ güven düzeyinde etkisinin olmadığ tespit edilmiştir. Tablo 4'te ilgili soru için yapılmıș Ki-kare testi sonuçları verilmiştir. 


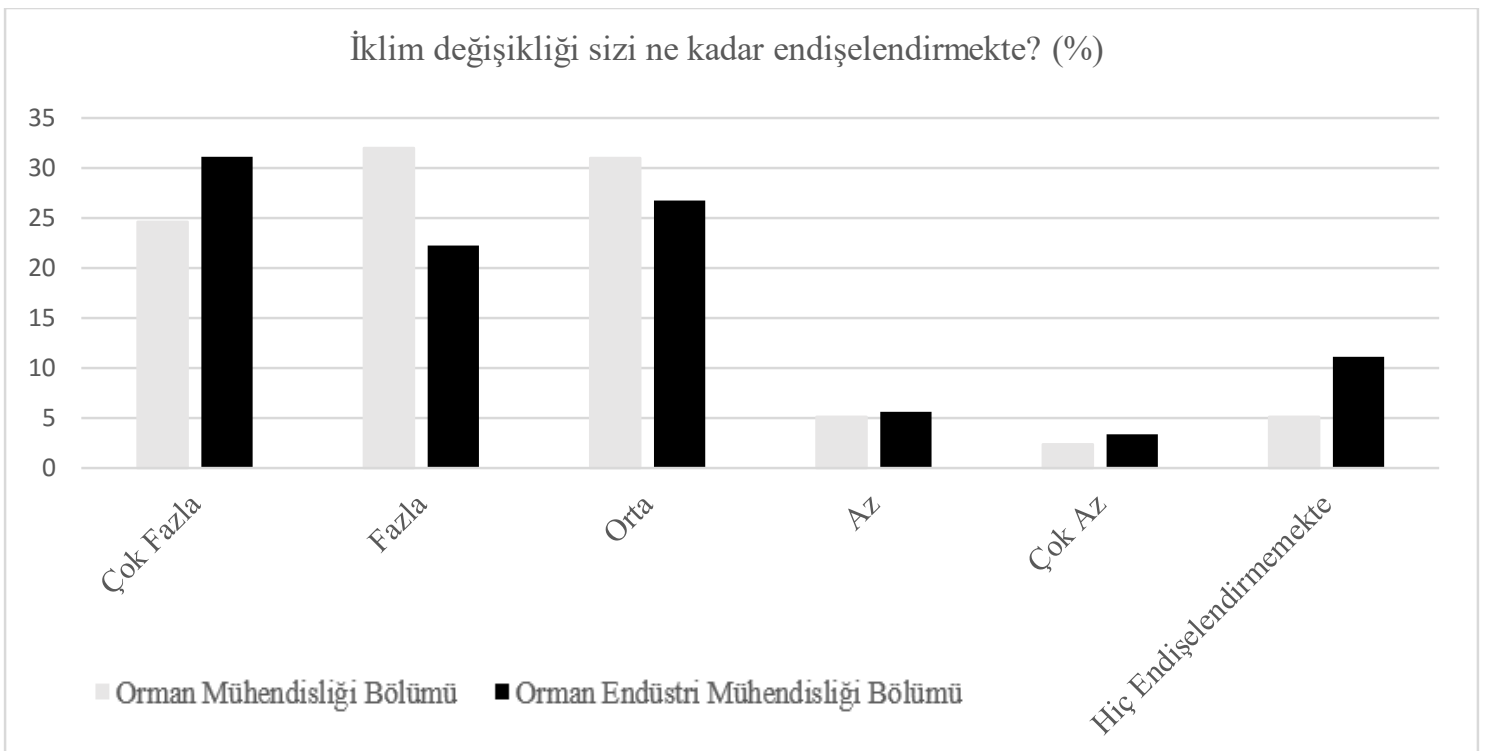

Şekil 4. “İklim değişikliği sizi ne kadar endişelendirmekte?” sorusuna verilen yanıtlan yüzdelik olarak gösterir grafik

Tablo 4. “İklim değişikliği sizi ne kadar endişelendirmekte?” sorusu için yapılan Ki-Kare testi tablosu

\begin{tabular}{|c|c|c|c|c|c|c|c|c|}
\hline \multirow{5}{*}{\multicolumn{2}{|c|}{ Çok fazla }} & & Bölüm & & & Cinsiyet & & \multirow[b]{2}{*}{$\mathrm{p}$} \\
\hline & & & $\begin{array}{l}\text { OM } \\
(n=216)\end{array}$ & $\begin{array}{l}\text { OEM } \\
(n=92)\end{array}$ & $\mathrm{p}$ & $\begin{array}{l}\text { Erkek } \\
(\mathrm{n}=216)\end{array}$ & $\begin{array}{l}\text { Kadin } \\
(\mathrm{n}=92)\end{array}$ & \\
\hline & & $\mathrm{n}$ & 54 & 29 & & 57 & 25 & \\
\hline & & \% Soru içerisinde & 65,1 & 34,9 & & 69,5 & 30,5 & \\
\hline & & $\%$ Grup içerisinde & 24,9 & 31,9 & & 26,4 & 27,2 & \\
\hline$\frac{\bar{d}}{0}$ & Fazla & $\mathrm{n}$ & 69 & 20 & & 61 & 28 & \\
\hline$\underbrace{m}$ & & \% Soru içerisinde & 77,5 & 22,5 & & 68,5 & 31,5 & \\
\hline$\vec{d}$ & & \% Grup içerisinde & 31,8 & 22,0 & & 28,2 & 30,4 & \\
\hline పี & Orta & $\mathrm{n}$ & 67 & 24 & & 62 & 29 & \\
\hline 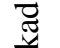 & & \% Soru içerisinde & 73,6 & 26,4 & & 68,1 & 31,9 & \\
\hline$\frac{1}{2}$ & & \% Grup içerisinde & 30,9 & 26,4 & 0,199 & 28,7 & 31,5 & 0,849 \\
\hline. & $\mathrm{Az}$ & $\mathrm{n}$ & 11 & 5 & & 12 & 4 & \\
\hline$\cdot \sqrt{\infty}$ & & \% Soru içerisinde & 68,8 & 31,3 & & 75,0 & 25,0 & \\
\hline ;50 & & $\%$ Grup içerisinde & 5,1 & 5,5 & & 5,6 & 4,3 & \\
\hline $\bar{z}$ & Çok az & $\mathrm{n}$ & 6 & 2 & & 6 & 2 & \\
\hline isn & & \% Soru içerisinde & 75,0 & 25,0 & & 75,0 & 25,0 & \\
\hline ( ) & & \% Grup içerisinde & 2,8 & 2,2 & & 2,8 & 2,2 & \\
\hline$\Xi$ & Hiç & $\mathrm{n}$ & 11 & 11 & & 18 & 4 & \\
\hline 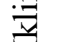 & endişelendirmemekte & \% Soru içerisinde & 52,4 & 47,6 & & 81,8 & 18,2 & \\
\hline & & \% Grup içerisinde & 5,1 & 11,0 & & 8,3 & 4,3 & \\
\hline
\end{tabular}

"Size göre bireylerin kendi başlarına iklim değişikliğini etkileyebileceğine ne kadar inanıyorsunuz?" sorusuna verilen cevaplar incelendiğinde;

Yapılan Ki-kare testi sonucunda bu soruya verilen cevaplarda öğrencilerin bölümlerinin ve cinsiyetlerinin $\% 95$ güven ile etkili olduğu tespit edilmiştir. OM öğrencilerinin verdikleri cevaplar arasında en yüksek orana $(\% 31,9)$ "Orta" cevab1 sahip olurken, OEM ögrencilerin verdikleri cevaplar arasında en yüksek orana (\%25) "Çok Fazla" cevab1 sahiptir. Hem OM hem de OEM öğrencileri arasında en az tercih edilen cevap, sırasıyla $\% 2,8$ ve $\% 2,2$ olmak üzere "Çok az" cevabıdır. Verilen cevaplar Şekil 5'deki gibi özetlenirken, soruya ilişkin Ki-kare testinin sonuçları Tablo 5 'te verilmiştir. 
"Size göre İklim Değișikliği Dünya'yı Ne Kadar Sürede Etkileyecektir?" sorusuna verilen cevaplar incelendiğinde;

Öğrencilerin bölümlerinin ve cinsiyetlerinin soruya verilen cevaplan $\% 95$ güven düzeyi ile etkilediği $(\mathrm{p}=0,003$ ve $\mathrm{p}=0,001$ ), yapılan Ki-kare testi sonucunda bulunmuştur. Soruya ilişkin Ki-kare testi sonucu Tablo 6'da verilmiştir. Her iki bölümün öğrencilerinin de en yüksek oranla (OM öğrencileri için \%47,7, OEM öğrencileri için \%50) verdikleri cevap "Halihazırda etkilemektedir" olmuştur. Öğrencilerin cinsiyetlerine göre verdikleri cevaplar; erkekler için \%43,7’lik, kadınlar için 59,1'lik oran ile "Halihazırda etkilemektedir" olmuştur. Her iki cinsiyet grubu için en az tercih edilen seçenek $\% 9$ ve $\% 0$ oranları ile "Hiçbir zaman etkilemeyecektir" seçeneği olmuştur. Şekil 6'de ilgili soruya verilen cevapları yüzdelik olarak gösteren grafik verilmiştir.

Size göre bireylerin kendi başlarına iklim değişikliğini etkileyebileceğine ne kadar inaniyorsunuz? $(\%)$

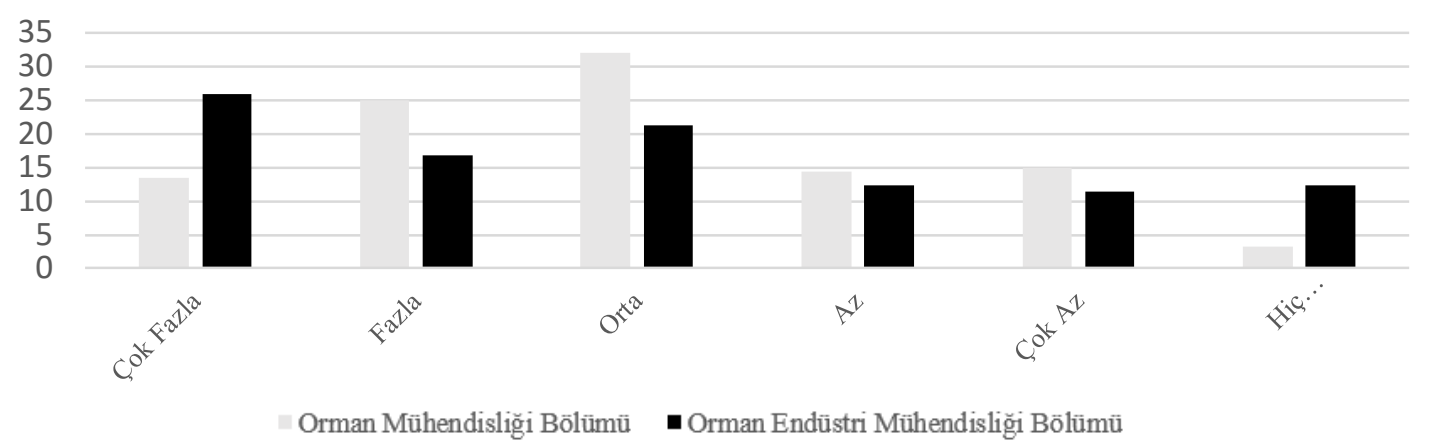

Şekil 5. "Size göre bireylerin kendi başlarına iklim değişikliğini etkileyebileceğine ne kadar inanıyorsunuz ?" sorusuna verilen yanıtları yüzdelik olarak gösterir grafik

Tablo 5. "Size göre bireylerin kendi başlarına iklim değişikliğini etkileyebileceğine ne kadar inanıyorsunuz ?"sorusuna ilişkin Ki-kare testi sonuçları

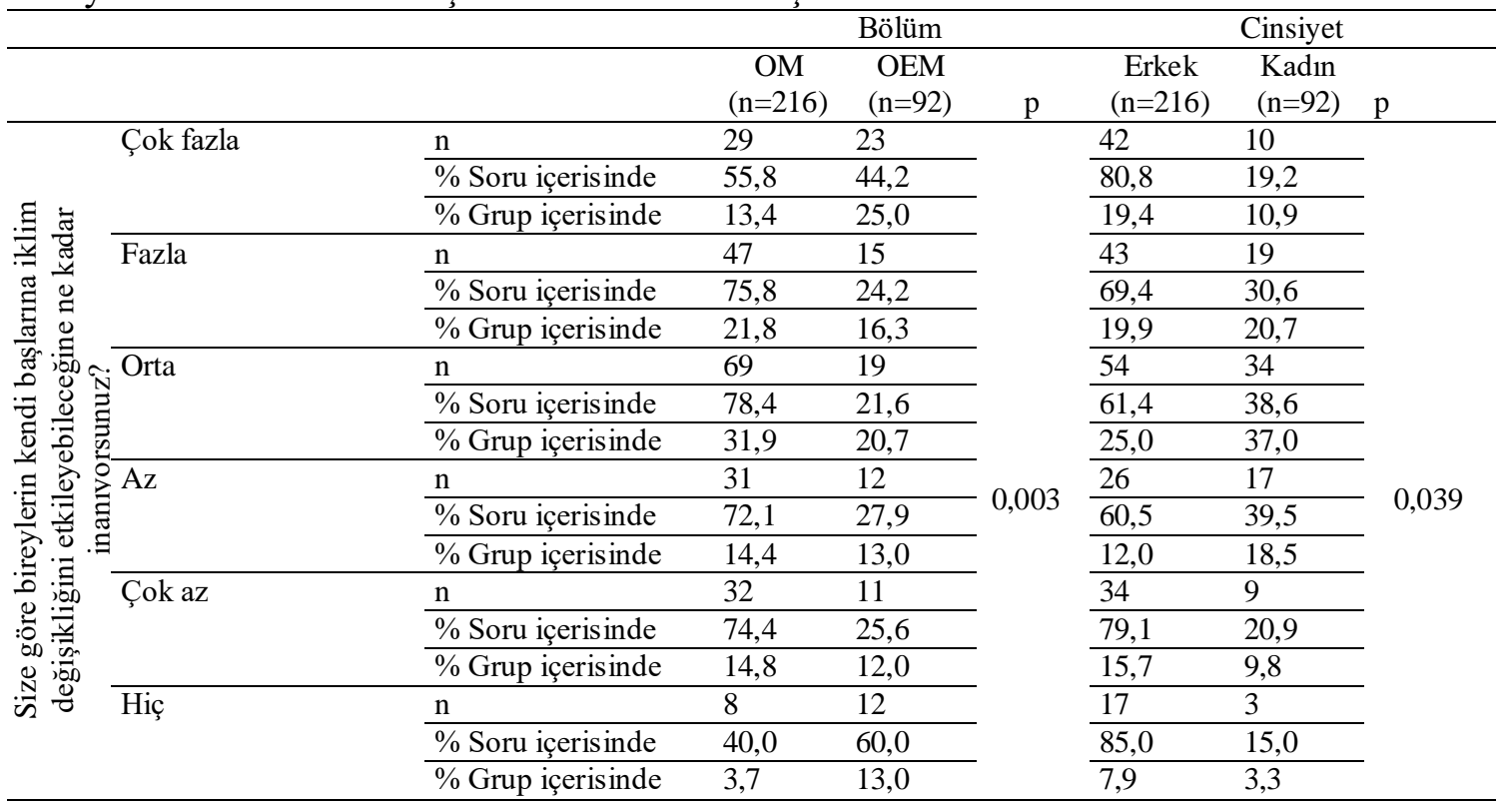


Size göre iklim değişikliği Dünya'yı ne kadar sürede etkileyecektir? (\%)

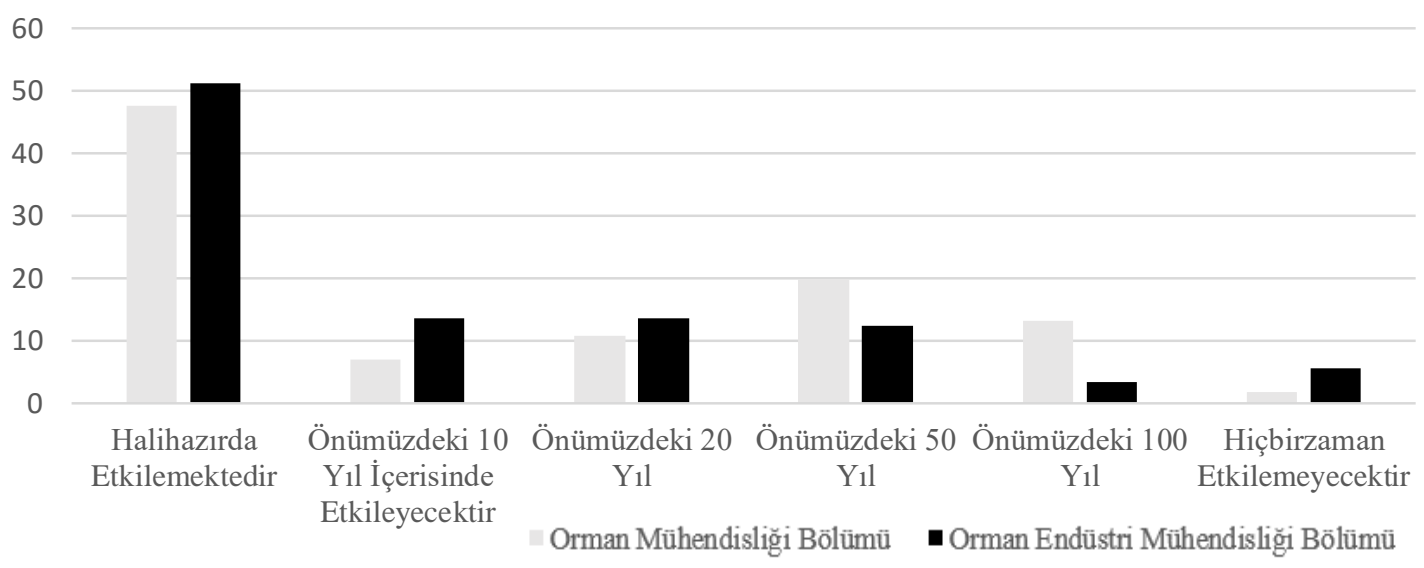

Şekil 6. "Size göre iklim değişikliği Dünya'yı ne kadar sürede etkileyecektir" sorusuna verilen cevapları gösterir grafik

Tablo 6. "Size göre iklim değişikliği Dünya'yı ne kadar sürede etkileyecektir" sorusuna ilişkin Ki-kare testi sonuçları

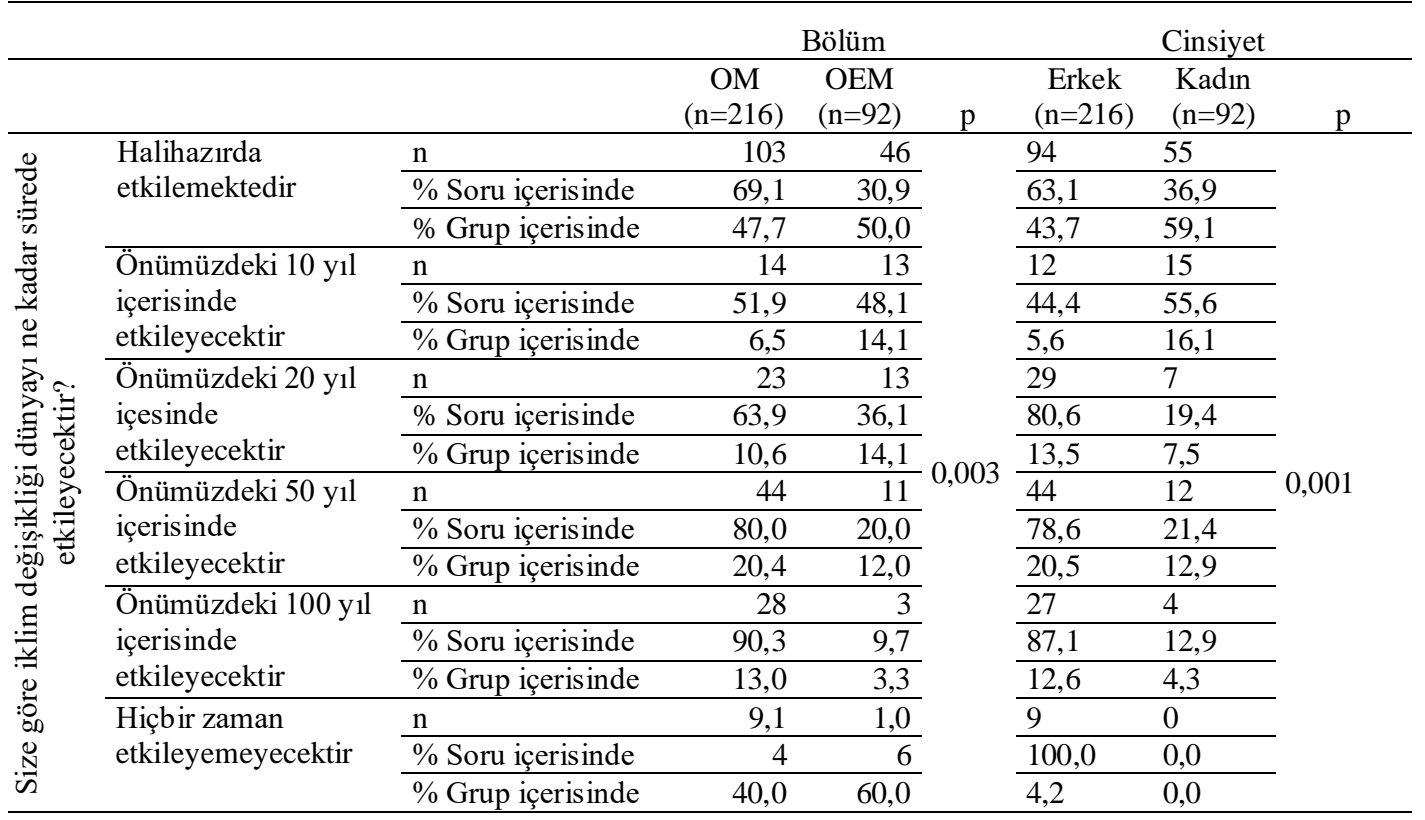

*İklim değişikliği ile ilgili bilgileri hangi kaynaklardan elde etmektesiniz? sorusuna verilen cevaplar incelendiğinde;

İlgili soru için yapılan Ki-Kare testi sonucunda $\% 95$ güven ile öğrencilerin okudukları bölümün, iklim değişikliği ile ilgili bilgileri elde ettikleri kaynakları etkilediği belirlenmiştir ( $p=0,001)$. Cinsiyetin ilgili soruya etkisinin olmadiğı tespit edilmiştir $(p=0,884)$. Ki-kare testi sonucu Tablo 7'de verilmiştir. Her iki bölüm öğrencilerinin de en yüksek oranla (OM için $\% 27,1$, OEM için \%32,4) verdikleri cevap "İnternet" olmuştur. OM öğrencileri, "Üniversite eğitiminden" bilgi edinme seçeneğini \%20,3'lük oran ile tercih etmelerine karşın, OEM öğrencileri \%7,1'lik oran ile bu seçeneği tercih etmişlerdir. Şekil 7'de ilgili soruya verilen cevaplar grafik üzerinde gösterilmiştir. 


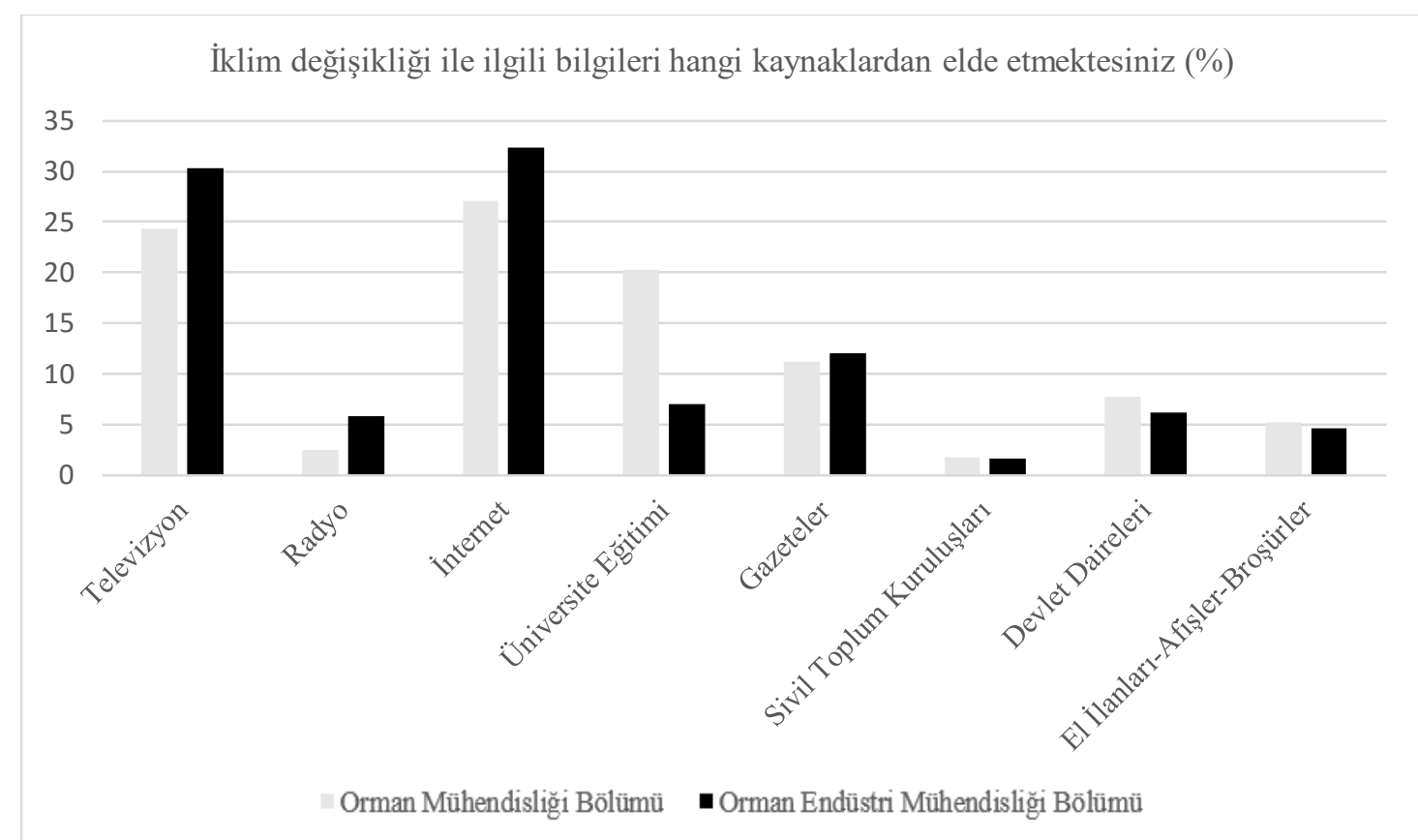

Şekil 7. "İklim değişikliği ile ilgili bilgileri hangi kaynaklardan elde etmektesiniz?" sorusuna verilen cevapların grafiği

Tablo 7. "İklim değişikliği ile ilgili bilgileri hangi kaynaklardan elde etmektesiniz?" sorusuna ilişkin Ki-kare testi sonuçlanı

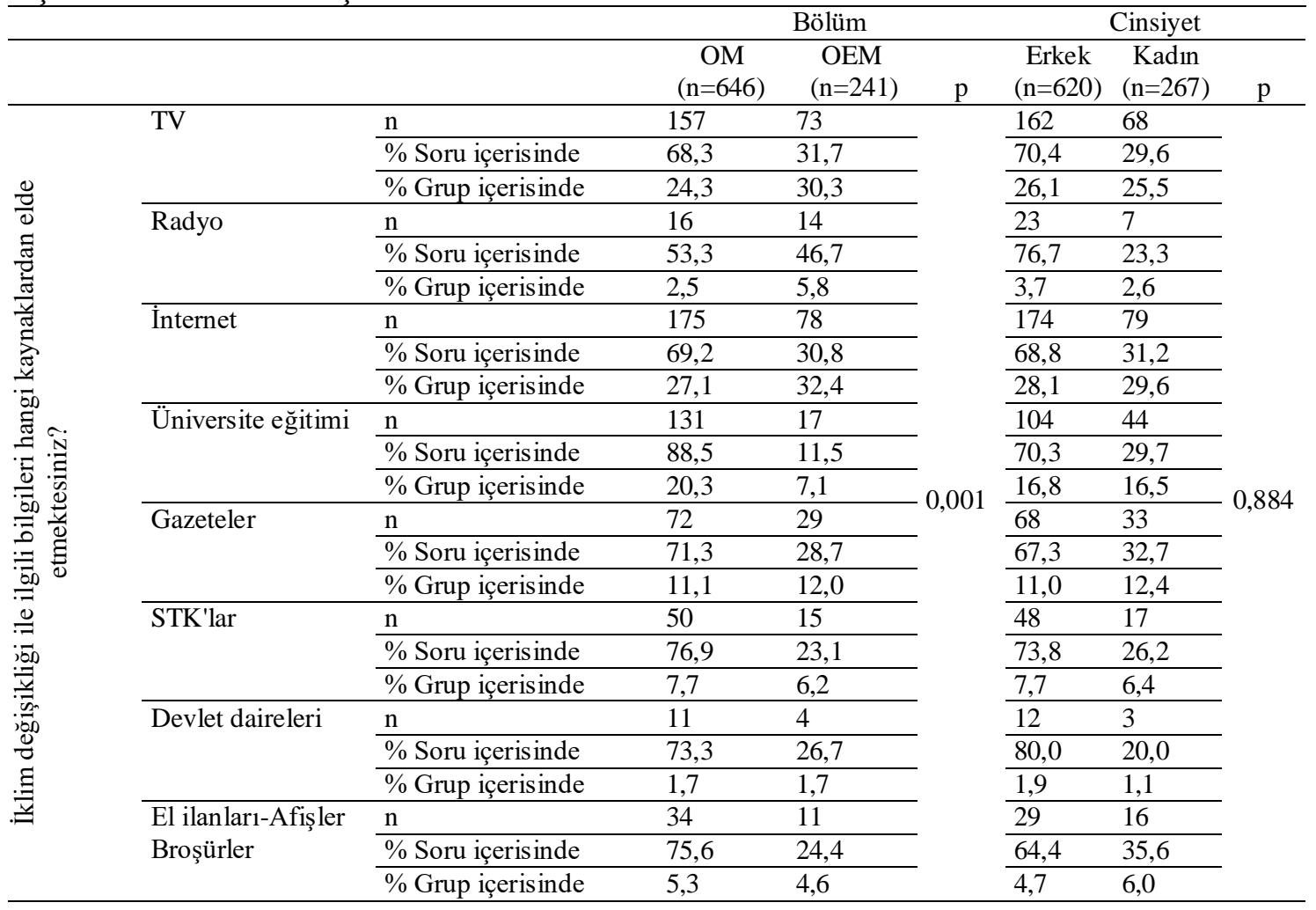


"İklim değişikliğinin önlenmesi konusunda herhangi bir proje, sivil toplum kuruluşu, organizasyon vb. gibi etkinliklerde bulundunuz mu?" sorusuna verilen cevaplar incelendiğinde;

Her iki bölüm içinde yüksek oran ile (OM için \%86,1, OEM için \%79,3) "Hayır" seçeneği öne çıkmıştır (Şekil 8). Ayrıca bu soruya cevap vermeyen 18 öğrenci mevcuttur. $\mathrm{Bu}$ soruya verilen cevaba cinsiyetin ve okudukları bölümün etkisinin olup olmadığı araştırılmış ve Ki-kare testi uygulanarak, sirasiyla $p=0,267$ ve $p=0,144$ değerleri bulunmuştur. Ki-kare testine ilişkin sonuçlar verilmiştir. Ho hipotezi reddedilerek "İklim Değişikliğinin önlenmesi konusunda herhangi bir proje, sivil toplum kuruluşu, organizasyon vb. gibi etkinliklerde bulunma durumuna" cinsiyetin ve okudukları bölümün etkisinin olmadığı \%95 güven ile istatistiksel olarak kabul edilmiştir (Tablo 8).

\section{"İklim değişikliğinin önlenmesinde alınabilecek önemler neler olmalıdır?" sorusuna verilen cevaplar incelendiğinde; \\ Soruya ilişkin yapılan Ki-kare testi sonucunda öğrencilerin okudukları bölümün ve cinsiyetlerinin verdikleri cevaplara $\% 95$ güven düzeyi ile etkisinin olmadığı belirlemiştir. Tablo 9'da Ki-kare testine ilişkin sonuçlar verilmiştir. $\mathrm{OM}$ ve $\mathrm{OM}$ öğrencileri sirasıyla \%14,9 ve \%15,7'lik oranla "Ormanların korunması ve varlığının arttırılması" önermesini seçtikleri en az olarak ise \%2,2' lik oranlarla iki bölüm öğrencilerinin de "Uçakla yapılacak olan yolculukların sinırlandırılması" önermesini seçtikleri belirlenmiştir. Şekil 9'da soruya ilişkin grafik verilmiştir.}

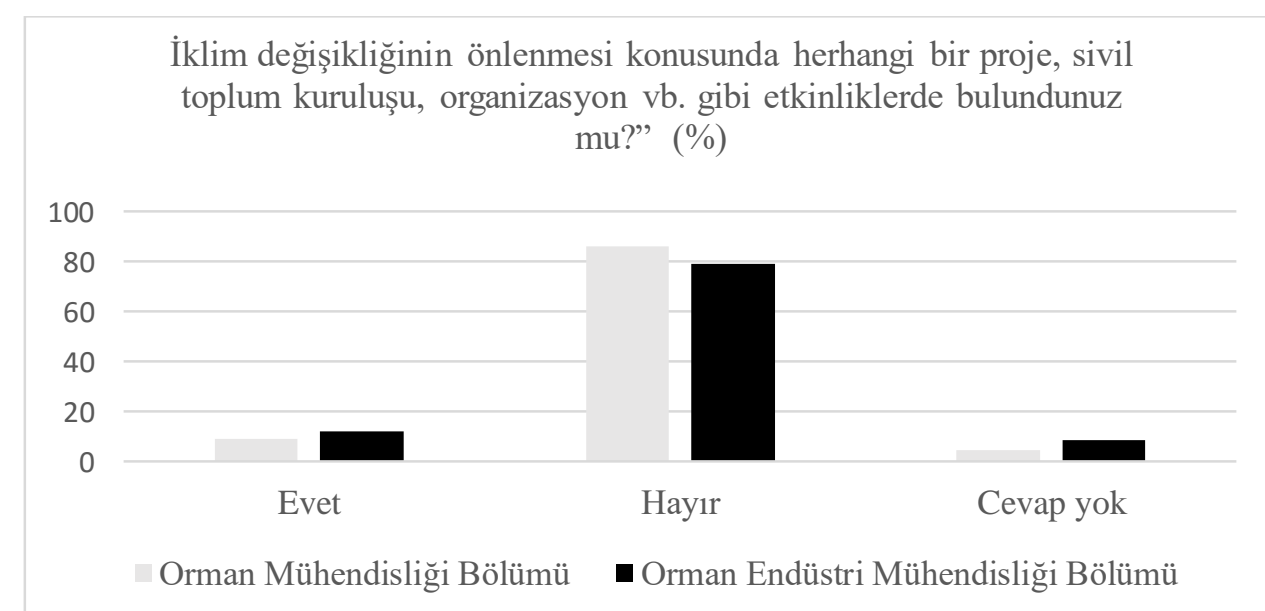

Şekil 8. "İklim değişikliğinin önlenmesi konusunda herhangi bir proje, sivil toplum kuruluşu, organizasyon vb. gibi etkinliklerde bulundunuz mu?" sorusuna verilen cevapların grafiğgi

Tablo 8. "İklim değişikliğinin önlenmesi konusunda herhangi bir proje, sivil toplum kuruluşu, organizasyon vb. gibi etkinliklerde bulundunuz mu?" sorusuna ilişkin Ki-kare testi sonuçları

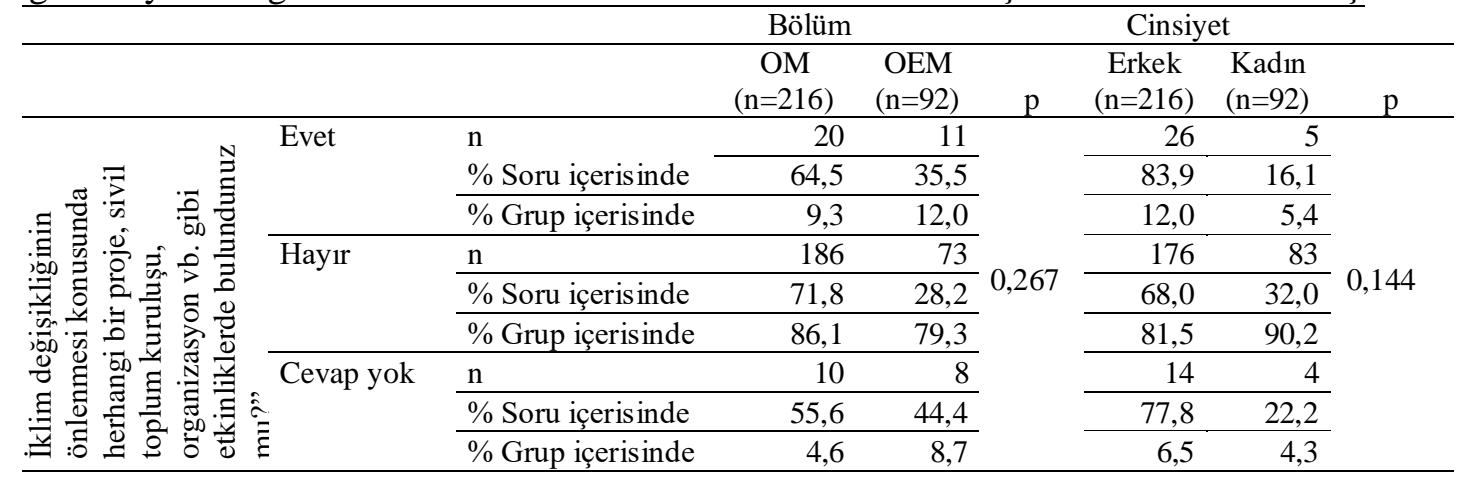




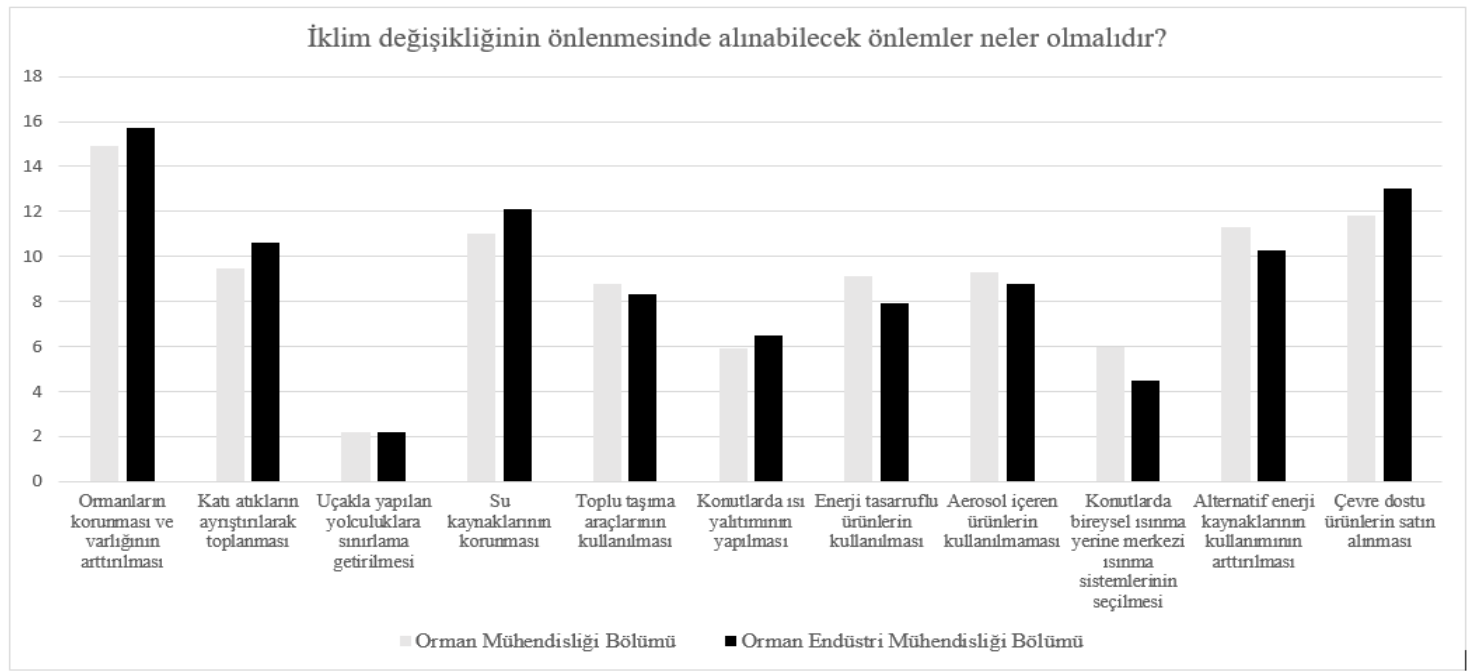

Şekil 9. “İklim değişikliğinin önlenmesinde alınabilecek önemler neler olmalıdır?” sorusuna verilen cevapların grafiği

Tablo 9. “İklim değişikliğinin önlenmesinde alınabilecek önemler neler olmalıdır?” sorusuna ilişkin Ki-kare testi sonuçları

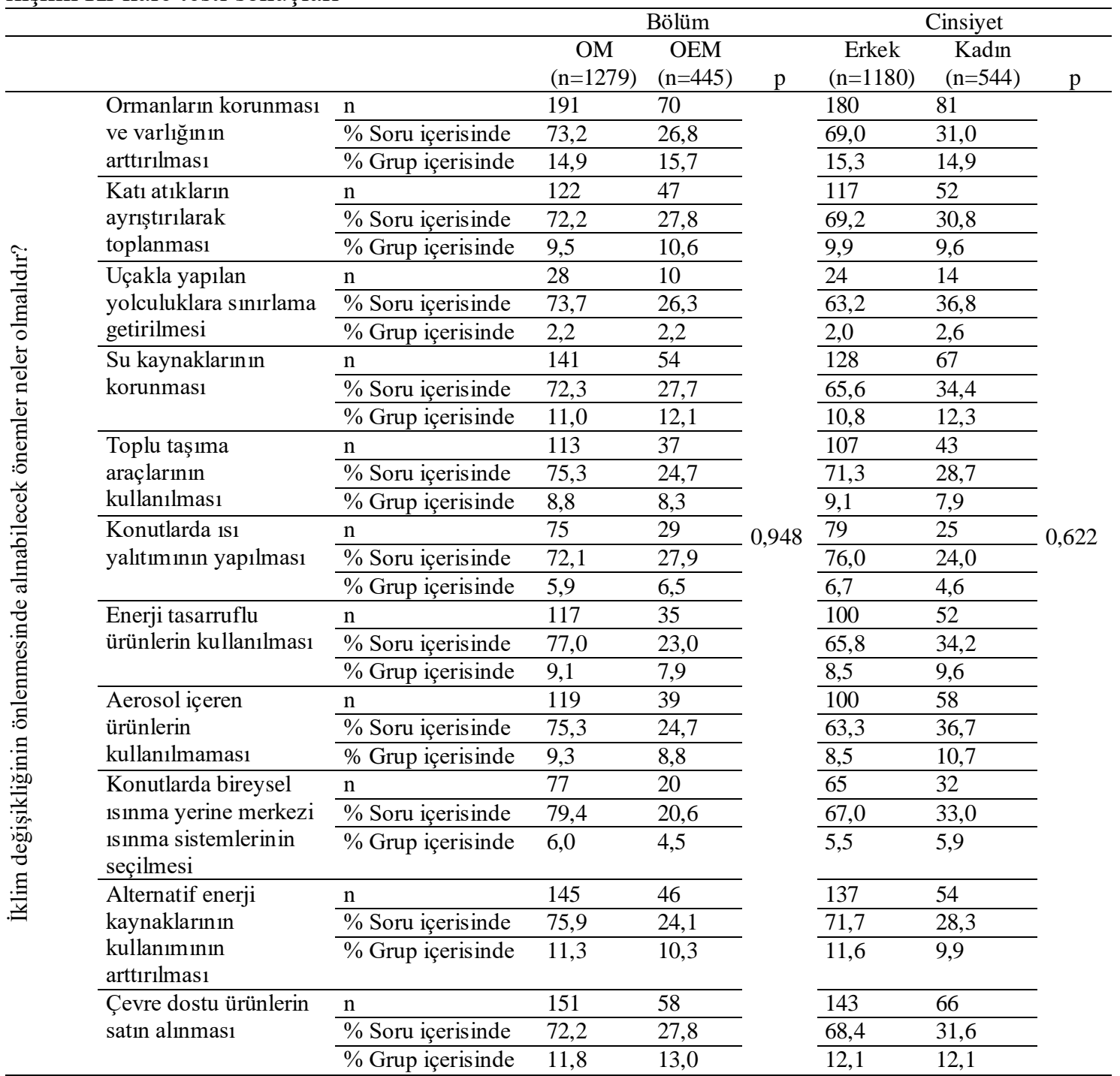


"Size göre gelecekte iklim değişikliği toplumsal yaşamda nasıl sonuçlar doğuracaktır?" sorusuna verilen cevaplar incelendiğinde;

OM ve OEM öğrencileri en çok \%19,2 ve $\% 21,5$ oranları ile "Su kullanımının sınırlandırılması" önermesini seçtikleri en az olarak ise iki bölüm öğrencilerinin de "Uçakla yapılacak olan yolculuklara sinırlama getirilmesi'

$(\% 5,8-\% 5,4)$

önermesini seçtikleri belirlenmiştir (Şekil 10).

$\mathrm{Bu}$ soru için yapılan Ki-kare testi sonucunda öğrencilerin okudukları bölümün ya da cinsiyetlerinin, bu soruya verdikleri cevabı etkilemediği \%95 güven düzeyi ile istatistiki olarak belirlenmiştir. Tablo 10'da ilgili sorunun Ki-kare testi sonucu verilmiştir.

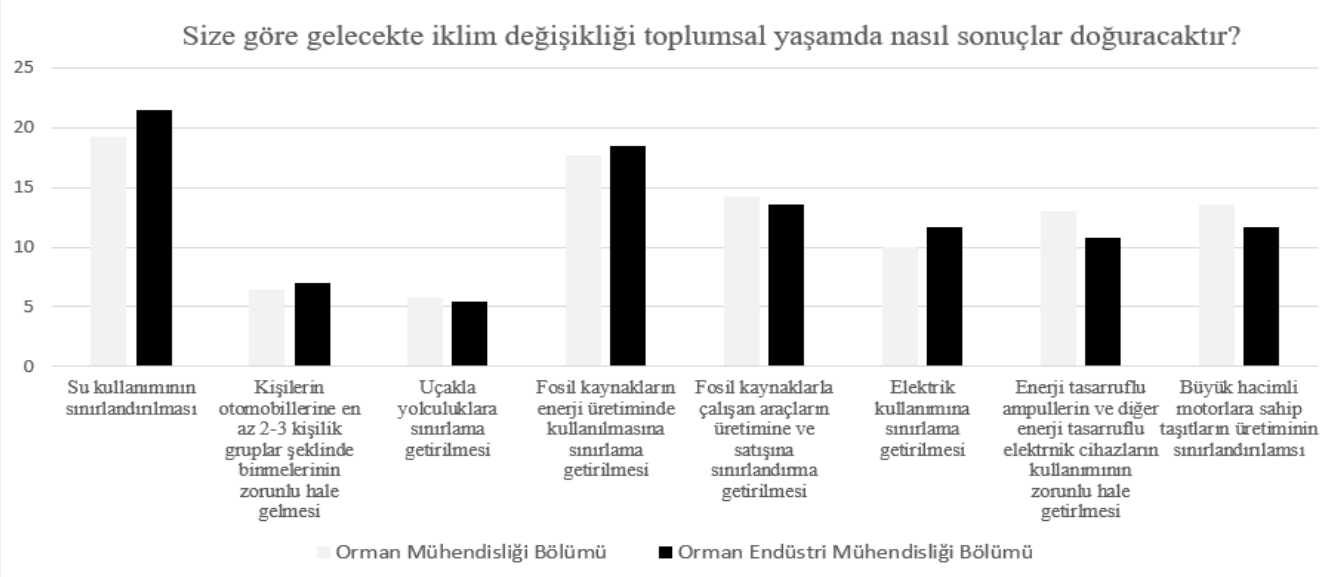

Şekil 10. "Size göre gelecekte iklim değişikliği toplumsal yaşamda nasıl sonuçlar doğuracaktır?" Sorusuna verilen cevapların grafiği

Tablo 10. "Size göre gelecekte iklim değişikliği toplumsal yaşamda nasıl sonuçlar doğuracaktır?" sorusuna ilişkin Ki-kare testi sonuçları

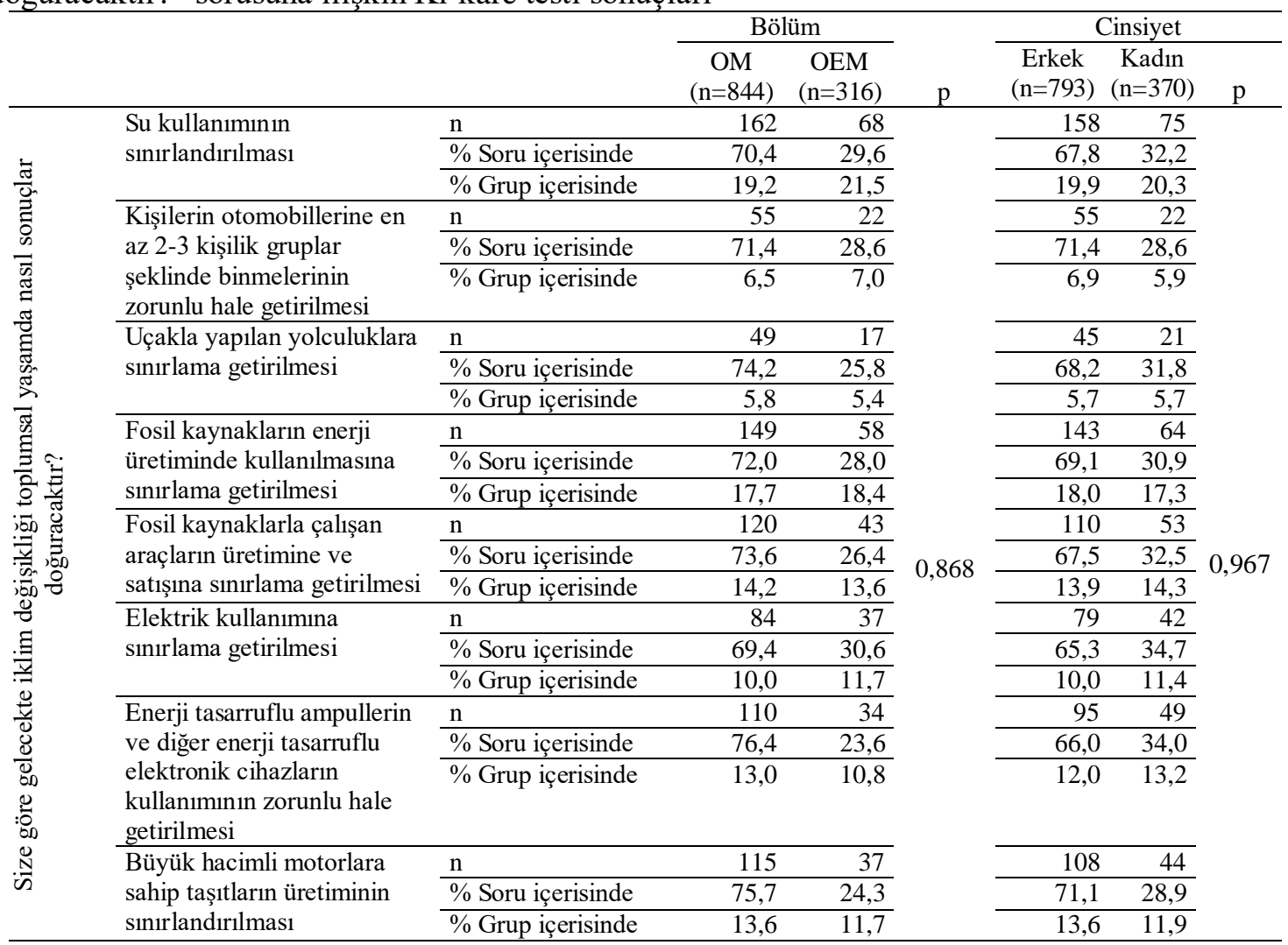




\section{Tartışma ve Sonuç}

"Sizce İklim Değiş̧ikliği ne anlama gelmektedir" sorusuna verilen cevaplarda "Mevsimsel düzensizlik" cevabının her iki bölüm öğrencileri için de en popüler cevap olması, iklim değişikliği kavramının sadece küresel 1sınma anlamına gelmediği ve literatürde tanımlanan haliyle her iki bölüm öğrencilerinin verdiği cevaplar arasında benzerlik olduğu tespit edilmiştir.

Anketlerin analizi ile bölüm öğrencileri arasında küresel iklim değişikliği kavramına inanmaları konusunda fark olmadığ1 bulunmuştur. Buradan hareketle, ekolojinin ve iklim ile ilgili diğer derslerin verildiği orman mühendisliği bölümü öğrencileri ile bu derslerin verilmediği orman endüstri mühendisliği öğrencilerinin aynı görüş içerisinde olmaları, konuya ilişkin yaratılmak istenen toplumsal algının oluşturulmaya başladığının göstergesidir.

Küresel iklim değişikliğinin sebebiyle ilgili olarak ögrencilere sunulan önermeler 1şı̆̆ında, Orman mühendisliği öğrencilerinin iklim değişikliğinin nedenini hızlı sanayileşme olarak tanımlaması, orman endüstri mühendisliği öğrencilerinin ise ormanların yok edilmesi olarak tanımlaması oldukça önemlidir. Çünkü ormanların yok edilmeden sürdürülebilir bir șekilde yönetimi için eğitilen orman mühendisliği öğrencileri, ormanların yok edilmesinin küresel iklim değişikliğinin etkilerinin artmasını bilmelerine rağmen özellikle Türkiye koşullarında herhangi bir ormansızlaşma söz konusu olmadığ 1 için bu algıyı ilk planda düşünmemişlerdir. Hızlı sanayileşmenin etkili olduğu bu alanlarda gerçekleşen karbon salınımın kendilerine göre daha fazla olduğunu düşündükleri için bu şıkk1 işaretlemişlerdir. Aynı zamanda ikinci olarak en yüksek oranda verdikleri "Ormanların yok edilmesi” cevabı, OM öğrencilerinin dünyada gelişen ormansızlaşma eğilimini takip ettiklerinin ve bu konu hakkında bilgi sahibi olduklarının göstergesidir. OEM öğrencileri ise güncel ve toplumsal bilgileri 1şı̆ıında ormansızlaşmanın daha önemli olduğunu düşündükleri ve daha çok ilgilendikleri alanın sanayi kuruluşlarını içerdiğinden dolayı bu konu hakkında bilgi sahibi oldukları için bu önermeyi tercih ettikleri düşünülmektedir.
Her iki bölüm öğrencilerinin, iklim değişikliği önleme ile ilgili herhangi bir organizasyon, STK veya bir kuruluş içinde yüksek oranla bulunmamaları konu ile ilgili olarak oldukça önem arz etmektedir. Ayrıca bu soruya 18 öğrencinin hiç cevap vermemesi, iki bölüm öğrencilerinin böyle önemli bir konuda oluşturulmuş topluluklara ne kadar uzak olduklarının bir göstergesi olmuştur.

Toplum içerisinde iklim değişikliğinin sonucu olarak susuzluk veyahut kuraklık çekileceği algısı ön planda olduğu için iki bölüm öğrencilerinin de "su kullanımının sınırlandırılması" cevabının tercih edildiği görülmüş ve kitleler üzerinde iklim değişikliği konusunun önlenmesi adına alg1 politikalarının başarılı olduğu ve toplumun bu konuda bilinçlenmeye başladığ söylenebilmektedir. Bunlarla birlikte yine en çok cevap verilen ikinci ve üçüncü sıradaki seçenekler incelendiğinde fosil yakıt konusunu içerdikleri gözükmektedir. Karbondioksit gazının salınımı ile sera etkisinin yaratılması ve bunun sonucunda iklim değişikliğinin gerçekleşmesi sebebiyle öğrencilerin bu konu ile ilgili algılarının doğru olduğu tespit edilmiştir. Fakat, "Uçaklarla yolculukların sinırlandırılması" cevabı ile aslında bireysel karbon ayak izinde \%14'lük gibi önemli bir yere sahip gezme, eğlence ve tatil aktivitelerinin yerine getirilmesinde çoğunlukla tercih bu ulaşım aracıyla ilgili önermeyi en az olarak seçmiş olmaları, yine iklim değişikliği konusunda toplumsal bilincin oluşturulması adına önem arz etmektedir.

Üniversite öğrencilerine iklim değişikliği ile ilgili yapılan diğer çalışmalarda, Bozdoğan ve Yanar (2009) çalışmanın yapıldığı öğretmen adaylarının konuyla ilgili bilgi düzeylerinin yeterli seviyede olmasına karşın yaklaşık yarısında bazı kavramsal yanılgılarının var olduğu tespit edilmiştir. Oğuz, Çakcı ve Kavasa (2011) tarafindan yapılan çalışmada ise Peyzaj Mimarlığı, Çevre Mühendisliği ve Şehir ve Bölge Planlama programlarında öğrenim gören öğrencilerin çevre ile ilgili konularda farkındalık ve duyarlılık seviyesinin okudukları sınıflardan bağımsız olduğu belirlenmiştir. Kastamonu Üniversitesi Orman Fakültesi öğrencileri ile yapılan bu çalışmada, diğer iki çalışmaya benzer 
sonuçlar elde edilmiştir. Anket sorularına verilen cevapların birçoğunda öğrencilerinin bölümlerinin ve cinsiyetlerinin etkisi olmadığı belirlenmiştir. İklim değişikliğinin tanımı ve önemi oldukça iyi bilinirken, iklim değişikliğinin önlenmesi konusunda herhangi bir sivil toplum kuruluşu veya organizasyon içinde bulunmamaları gündelik hayatlarında konuya aynı önemi göstermedikleri tespit edilmiştir.

\section{Kaynaklar}

Bayrak, M. R. 2012. Sürdürülebilir Kalkınma İçin Türkiye'de Düşük Karbon Ekonomisi ve Kyoto Protokolü'nün Finansman Kaynakları, Tarih Kültür ve Sanat Araştırmaları Dergisi (ISSN: 2147-0626), Cilt 1, Sayı 4, Karabük.

Bulut, A. 2012. Ormanların Karbon Depolama Kapasitesinin Üç Farklı Uydu Görüntüsü Kullanılarak Uzaktan Algılama Yöntemi İle Belirlenmesi (Alacadağ Orman İşletme Şefliği Örneği ), Karadeniz Teknik Üniversitesi Fen Bilimleri Enstitüsü, Yüksek Lisans Tezi, Trabzon.

Bozdoğan, A. E., Yanar O. 2010. Sınıf Öğretmeni Adaylarının Küresel Isınmanın Gelecek Yüzyıldaki Etkilerine İlişkin Görüşleri, Karadeniz Fen Bilimleri Dergisi, Sonbahar, 2010, Y1l: 1 Cilt: 1, Sayı: 2, Sayfa: 48-6.

Erol, G.H.,Gezer, K. 2006. Prospective of elementary school teachers' attitudes toward environment and environmental problems. International Journal of Environmental and Science Education 1.1 65-77.

Houghton, R.A., Woodwell, G.M., 1989. Global climatic change. Scient. Am. 260, 36-44

İncekara S., Tuna, F. 2010. Ortaöğretim Öğrencilerinin Çevresel Konularla İlgili Bilgi Düzeylerinin Ölçülmesi: Çankırı İli Örneği, Marmara Üniversitesi Coğrafya Dergisi, Say1:22, Syf. 168-182. İstanbul.

Mitchell, J.F.B., 1989. The greenhouse effect and climate change. Rev. Geophy. 27, 115-139.

Oğuz, D., Cakcı, I., Kavasa, S. 2011. Yüksek Öğretimde Öğrencilerin Çevre Bilinci, SDÜ Orman Fakültesi Dergisi , 12: 34-3.

Öztürk, K. 2002. Küresel İklim Değişikliği ve Türkiye'ye Olası Etkileri, G.Ü. Gazi Eğitim
Fakültesi Dergisi, Cilt 22, Sayı 1, Syf. 47-65, Ankara.

Short, F.T. ve Neckles, H. 1998. The effects of global climate change on seagrasses, Aquatic Botany 63 169-196.

Şama, E. 2003. Öğretmen Adaylarının Çevre Sorunlarına Yönelik Tutumları, G.Ü. Gazi Eğitim Fakültesi Dergisi Cilt 23, Sayı 2, Syf. 99-110, Ankara

Şimşek, E.G. 2016. Uluslararası Hukukta Doğal Hayatın Korunması, Beta Basım A.Ș., Syf. 24., İstanbul.

Türkeş, M. 2000. 'Küresel 1sınma, İklim Değişikliği Çerçeve Sözleşmesi ve Kyoto Protokolü', 6. Uluslararası Kojenerasyon ve Çevre Konferansı ve Sergisi (25-26 Mayıs 2000 İstanbul) Bildiriler Kitab1, 147-162, Cogen Europe ve Cogen Association, İstanbul.

Türkeș, M. 2001. Küresel iklimin korunması, İklim Değișikliği Çerçeve Sözleșmesi ve Türkiye. Tesisat Mühendisliği, TMMOB Makina Mühendisleri Odası, Süreli Teknik Yayın 61: 14-29.

URL 1. https://www.co2.earth/ Erişim Tarihi Kasım 2016.

URL 2.

http://www.giss.nasa.gov/research/news/2016 0120/ Erișim Tarihi Kasım 2016.

URL 3. http://www.karbonayakiziniziazaltin.com/ Erişim Tarihi Eylül 2016.

Worrest, R.C. 1989. What are the effects of UV-B radiation on marine organisms? In: Schneider, T. et al. (Eds.), Atmospheric Ozone Research and its Policy Implications. Elsevier, Amsterdam, The Netherlands, pp. $269 \pm 278$.

Yalçın, A. Z. , 2010. "Sürdürülebilir Kalkınma İçin Düşük Karbon Ekonomisinin Önemi ve Türkiye İçin Bir Değerlendirme" Balıkesir Üniversitesi Sosyal Bilimler Enstitüsü Dergisi Cilt 13 Sayı 24, Balıkesir.

Yılmaz, A., Morgil, İ., Aktuğ, P., Göbekli, İ. 2002. Ortaöğretim ve Üniversite Öğrencilerinin Çevre, Çevre kavramları ve Sorunları Konusundaki Bilgileri ve Öneriler, Haccettepe Üniversitesi Eğitim Fakültesi Dergisi, 22:15162, Ankara. 